\title{
Biochar and Trichoderma spp. in management of plant diseases caused by soilborne
}

\section{fungal pathogens: a review and perspective}

\author{
Biochar e Trichoderma spp. no manejo de doenças de plantas causadas por patógenos fúngicos do \\ solo: uma revisão e perspectiva
}

Biochar y Trichoderma spp. en el manejo de enfermedades de las plantas causadas por hongos patógenos transmitidos por el suelo: una revisión y perspectiva

Received: 10/28/2021 | Reviewed: 11/06/2021 | Accept: 11/17/2021| Published: 11/27/2021

Erika Valente de Medeiros

ORCID: https://orcid.org/0000-0001-5543-9414 Universidade Federal do Agreste de Pernambuco, Brazil

E-mail: erika.valente@ufape.edu.br

Lucas Figueira da Silva

ORCID: https://orcid.org/0000-0002-6537-9125 Universidade Federal do Agreste de Pernambuco, Brazil E-mail: lucas_f.silva@hotmail.com

Jenifer Sthephanie Araújo da Silva

ORCID: https://orcid.org/0000-0002-5064-669X

Universidade Federal do Agreste de Pernambuco, Brazil

E-mail: jenifersthephanie12@hotmail.com

Diogo Paes da Costa

ORCID: https://orcid.org/0000-0002-8551-7345

Universidade Federal do Agreste de Pernambuco, Brazil

E-mail: diogocosta1@yahoo.com.br

Carlos Alberto Fragoso de Souza

ORCID: https://orcid.org/0000-0002-8388-4897

Universidade Federal do Agreste de Pernambuco, Brazil

E-mail: carlos_fragoso1@ hotmail.com

Lúcia Raquel Ramos Berger

ORCID: https://orcid.org/0000-0002-5039-8198

Universidade Federal do Agreste de Pernambuco, Brazil

E-mail: luciaraquelramosberger@gmail.com

José Romualdo de Souza Lima

ORCID: https://orcid.org/0000-0001-9535-9208

Universidade Federal do Agreste de Pernambuco, Brazil

E-mail: romualdo.lima@ufape.edu.br

Claude Hammecker

ORCID: https://orcid.org/ 0000-0001-5594-4891

Soil-Agrosystem-Hydrosystem interaction lab-LISAH, France

E-mail: claude.hammecker@ird.fr

\begin{abstract}
A better understanding of the use of biochar with Trichoderma spp. (TRI), considered the most studied tool for biological control, would increase our ability to set priorities. However, no studies exist using the two inputs on plant disease management. Here, we hypothesized that biochar and TRI would be used for the management of soilborne plant pathogens, mainly due to changes in soil properties and its interactions. To test this hypothesis, this review assesses papers that used biochar and TRI against plant diseases and we summarize the handling mechanisms for each input. Biochar acts by mechanisms: induction to plant resistance, sorption of allelopathic and fungitoxic compounds, increase of beneficial microorganisms, changes the soil properties that promote health and nutrient availability. Trichoderma as biocontrol agents by different mechanisms: mycoparasitism, enzyme and secondary metabolic production, plant promoter agent, natural decomposition agent, and biological agent of bioremediation. Overall, our findings expand our knowledge about the reuse of wastes transformed in biochar combined with Trichoderma has potential perspective to formulate products as alternative management tool of plant disease caused by soilborne fungal pathogen and add important information that can be suitable for development of strategy for use in the global health concept.
\end{abstract}

Keywords: Black carbon; Biocontrol; Soil Health; Management practices; Plant growth-promoting. 


\begin{abstract}
Resumo
Uma melhor compreensão do uso do biochar com Trichoderma spp. (TRI), considerada a ferramenta mais estudada para o controle biológico, aumentaria nossa capacidade de estabelecer prioridades. No entanto, não existem estudos utilizando os dois insumos no manejo de doenças de plantas. Aqui, hipotetizamos que o biochar e o TRI seriam usados para o manejo de patógenos vegetais transmitidos pelo solo, principalmente devido às mudanças nas propriedades do solo e suas interações. Para testar essa hipótese, esta revisão avalia artigos que usaram biochar e TRI contra doenças de plantas e resumimos os mecanismos de manuseio para cada entrada. Biochar atua por mecanismos: indução à resistência das plantas, sorção de compostos alelopáticos e fungitóxicos, aumento de microrganismos benéficos, altera as propriedades do solo que promovem a saúde e a disponibilidade de nutrientes. Trichoderma como agente de biocontrole por diferentes mecanismos: micoparasitismo, produção enzimática e metabólica secundária, agente promotor de plantas, agente de decomposição natural e agente biológico de biorremediação. No geral, nossos resultados expandem nosso conhecimento sobre o reaproveitamento de resíduos transformados em biochar combinado com Trichoderma, perspectiva potencial para formular produtos como ferramenta alternativa de manejo de doenças de plantas causadas por patógenos fúngicos de solo e adicionar informações importantes que podem ser adequadas para o desenvolvimento de estratégia para uso em o conceito de saúde global.
\end{abstract}

Palavras-chave: Carbono negro; Biocontrole; Saúde do solo; Práticas de manejo; Promoção de crescimento de plantas.

\title{
Resumen
}

Una mejor comprensión del uso de biocarbón con Trichoderma spp. (TRI), considerada la herramienta más estudiada para el control biológico, aumentaría nuestra capacidad para establecer prioridades. Sin embargo, no existen estudios que utilicen los dos insumos sobre el manejo de enfermedades de las plantas. Aquí, planteamos la hipótesis de que el biocarbón y el TRI se utilizarían para el manejo de patógenos de plantas transmitidos por el suelo, principalmente debido a cambios en las propiedades del suelo y sus interacciones. Para probar esta hipótesis, esta revisión evalúa artículos que utilizaron biochar y TRI contra enfermedades de las plantas y resumimos los mecanismos de manejo para cada entrada. El biocarbón actúa por mecanismos: inducción a la resistencia de las plantas, sorción de compuestos alelopáticos y fungitóxicos, aumento de microorganismos benéficos, cambiá-las propiedades del suelo que promueven la salud y la disponibilidad de nutrientes. Trichoderma como agentes de biocontrol por diferentes mecanismos: micoparasitismo, producción enzimática y metabólica secundaria, agente promotor vegetal, agente de descomposición natural y agente biológico de biorremediación. En general, nuestros hallazgos amplían nuestro conocimiento sobre la reutilización de desechos transformados en biocarbón combinado con Trichoderma tiene una perspectiva potencial para formular productos como una herramienta de manejo alternativa de enfermedades de las plantas causadas por patógenos fúngicos transmitidos por el suelo y agregar información importante que puede ser adecuada para el desarrollo de una estrategia de uso en el concepto de salud global.

Palabras clave: Carbono negro; Biocontrol; Salud del suelo; Prácticas de manejo; Promoción del crecimiento vegetal.

\section{Introduction}

The growing need for a sustainable food production represents a major challenge for crop producers. The increase in demand for healthier food and the exponential growth of the world population pose difficulties to food production, intensified by climatic adversities as well as constant attacks of pests and diseases that compromise crop production. Plant diseases caused by soilborne pathogens decrease crop yields, resulting in great socioeconomic damage, due to the difficulty to diagnose and control these diseases, especially when symptoms occur only in the roots and not observed in the shoots (Ghorbanpour et al., 2018). Soil pathogens comprise fungi, oomycetes, bacteria, viruses, and nematodes (Montiel-Rozas et al., 219). Fungi stand out as the largest group causing root diseases in cropped plant species, since they occur in all agricultural ecosystems. Although diverse, soil pathogens share similarities, such as the influence by biotic and abiotic soil components, poor dispersion (Liu et al., 2020), as well as the capacity of developing structures of resistance that allow these microorganinsms to survive long periods in the soil without a host plant, hindering their management.

Thus, research on efficient and sustainable management strategies is essential for a more integrative agriculture. The use of synthetic chemicals is the main method of pest and disease control in agriculture. However, the indiscriminate use of synthetic products has increased the resistance of pest and pathogens, damaged the environment, and affected human health (Montiel-Rozas et al., 219). Alternative techniques for disease control, such as biological control (Zin \& Badaluddin, 2020) has grown substancially in recent years with use of Bacillus spp., Metarhizium spp., and Trichoderma spp. Fungi of the genus 
Trichoderma are agents of importance in agriculture for biological control, due to their high potential as antagonist against many phytopathogens. The capacity of Trichoderma to remain in the soil for long periods characterizes an advantage for a preventive biological control (Da Silva et al., 2016). In addition, this fungus promotes the growth of host plants and stimulates plant resistance to the attack by pathogenic microorganisms that penetrate and colonize the root surface, limiting plant growth (Montiel-Rozas et al., 219).

In recent years, biochar has been considered an important issue in management of soilborne phytopatogens since they provide several benefits for sustainable food production (Medeiros et al., 2021). Biochar is a solid compound that results from organic matter decomposition under high temperatures under low oxygen concentrations in a pyrolysis process (Lehmann et al., 2011). Silva et al. (2021) has studied the use of biochar as a low-cost alternative for waste reuse in agriculture, benefiting the soil, microorganisms, culture, and the environment. Biochar improves the soil physical, chemical, and biological parameters. It also increases retention of water and nutrients, favoring carbon sequestration and benefiting the soil microbiota (Lima et al., 2018; Medeiros et al., 2020a). Biochar has been used for the management of plant diseases caused by pathogens in the soil (Medeiros et al., 2021).

However, studies on the use of biochar combined with Trichoderma are still incipient. Therefore, it is crucial to investigate their use in combination to provide farmers a tool for the management of plant diseases caused by soilborne pathogens. Here, we hypothesized that the co-application of biochar and TRI would be used to the management of soilborne plant pathogen, mainly due changes soil properties and its interactions. To test this hypothesis, this review assesses twenty papers with biochar and thirty-three with TRI used as alternative tool to managemen plant diseases caused by soilborne pathogen and we summarize the handling mechanisms for each input.

\section{Methodology}

This study is a narrative review about the use of Biochar and Trichoderma spp. in the management of plant diseases caused by soil fungal pathogens. The selected literatures were extracted from the platforms: SciELO, ScienceDirect, Elsevier, PubMed, SpringerLink and Jornal CAPES.

\section{Development}

\subsection{Strategies for managing diseases caused by soilborne pathogens}

Different strategies have been used to manage plant diseases caused by soil pathogens, such as the use of resistant cultivars, crop rotation, addition of organic matter sources, physical, chemical, and biological control techniques (Kazerooni et al., 2020; Medeiros et al., 2021). The use of resistant cultivars is a management strategy used in cropped areas with a history of pathogen infestation in the soil. This technique must be handled with care, as pathogens have a great capacity to overcome plant resistance, making them more susceptible to the disease. Crop rotation consists of alternating cultivation of different plant species to avoid as much as possible the contact of pathogens with susceptible crops (Hong et al., 2020). The introduction of new crops through this method allows the entry of microorganisms antagonistic against several soil phytopathogens (Larkin $\&$ Brewer, 2020).

On the other hand, the use of chemical control has increased considerably due to the expansion of agricultural areas over the years. This method involves the use of chemical compounds with specific action mechanisms that eradicate target microorganisms (Montiel-Rozas et al., 219). However, it is a practice that must be adopted carefully due to toxicological effects and occurrence of resistant phytopathogens (Coelho et al., 2020).

The biological control uses microorganisms that reduce the attack of pathogenic organisms through various 
interactions, such as antagonism, in which an organism produces substances that inhibit the development of others (Silva et al., 2017). Several microorganisms have been studied regarding mechanisms for their potential use as biocontrol agents. Fungi of the genus Trichoderma have mechanisms, such as antibiosis, predation, competition, and even induction of resistance to plants (Zin \& Badaluddin, 2020). Therefore, the use of these fungi reduces the use of chemicals in agriculture, mitigating damages to the environment and providing more sustainable production.

\subsection{Use of Trichoderma spp. in the biological control of plant diseases}

The genus Trichoderma is widely studied and has several applications in the industry, in the environment, and mainly in agriculture. Trichoderma is known for the diverse benefits to plants, promoting plant growth (Medeiros et al., 2020a), producing phytohormones and enzymes that increase the root absorption area (Lee et al., 2016). These fungi promote phosphate solubilization (Chagas et al., 2017) and insoluble micronutrient, improving absorption of water and nutrients and inducing resistance to plants, contributing to the production of more vigorous plants. Trichoderma is a natural decomposition agent and thus used as a biological agent of bioremediation.

Moreover, it is the most studied species for biocontrol of plant disease (Zin \& Badaluddin, 2020), for diverse soilborne pathogens (Elshahawy \& El-Mohamedy, 2019; Lu et al., 2020). Different pathosystems using Tricoderma spp. in the biocontrol of plant diseases are shown in Table 1. For example, isolates of Trichoderma harzianum inhibited the growth of pathogen Macrophomina phaseolina (Tassi) Goind, a causal agent of coal rot in soybean plants, increasing the length of stem and roots of plants in the field (Khalili et al., 2016). Sallam et al. (2019) evaluated the antagonistic function of isolates of Trichoderma spp. and observed that all isolates inhibited the action of the pathogen Fusarium oxysporum f.sp. lycopersici, the causal agent of tomato wilt. The most commercialized and used strains worldwide are T. harzianum (Table 1), followed by $T$. atroviride, T. asperellum, T. lignorum, T. catenulatum, T. koningiopsis, T. virens, T. fertile, and T. stromaticum (Bettiol et al., 2019).

\subsection{Plant disease control mechanisms by Trichoderma spp.}

The antagonism of Trichoderma involves a variety of mechanisms that confer success to the biocontrol of phytopathogens. Trichoderma is capable of surviving in unfavorable conditions and it also has a high reproductive capacity, efficient use of nutrients, modification of rhizosphere, root colonization, induction of resistance to host plants, and great aggressiveness towards phytopathogens (Kumar et al., 2017). Trichoderma also shows competition with other microorganisms for space and nutrients, inducing systemic resistance of plants to pathogens (Wang et al., 2020).

Mycoparasitism relationships are mechanisms for the biocontrol of pathogens that the Trichoderma species most use. Antagonistic fungi recognize and attack pathogens directly, limiting their growth by strangling their hyphae, cause pathogen death (Alfiky, 2019), and excrets secondary metabolites and enzymes, such as exoglucanases, chitinazes, and proteases that degrade the cell wall of phytopathogenic fungi (Da Silva et al., 2016).

Trichoderma harzianum releases peptaibols, a family of antimicrobial peptides produced as secondary metabolism (Nawrocka \& Małolepsza, 2013). These peptaibols inhibit the glucan synthase activity in pathogenic fungi $\beta-(1,3)$, an enzyme that synthethizes $\beta-(1,3)$ glucan and reduces the blocks by synthesizing cell wall polysaccharides due to the incorporation of uridine diphosphate (UDP) and glucose (UDP-Glc) (Zin \& Badaluddin, 2020).

Briefly, the mechanisms used by Trichoderma to control plant diseases caused by soilborne pathogens are: (i) mycoparasitism, (ii) enzyme and secondary methabolic production, (iii) plant promoter agent, (iv) natural decomposition agent, and (v) biological agent of bioremediation. 
Research, Society and Development, v. 10, n. 15, e296101522465, 2021

(CC BY 4.0) | ISSN 2525-3409 | DOI: http://dx.doi.org/10.33448/rsd-v10i15.22465

Tabela 1. Studies that used Trichoderma spp. as a strategy to manage plant diseases caused by soilborne pathogen.

\begin{tabular}{|c|c|c|c|}
\hline Trichoderma species & Crop & Phytopathogen & Reference \\
\hline $\begin{array}{l}\text { Trichoderma parareesei, } \\
\text { T. harzianum, T. koningii }\end{array}$ & Banana & Fusarium oxysporum f. cubense & Al-ani \& Albaayit, (2018) \\
\hline $\begin{array}{l}\text { T. harzianum, T. koningii, T. pseudokoningii, T. viride, T. virens, } \\
\text { T. atroviride, and T. reesei }\end{array}$ & Brinjal & Fusarium oxysporum f. melongenae & Cherkupally et al., (2017) \\
\hline T. asperellum, T. harzianum, T. citrinoviride, and T. erinaceum & Carnation & Sclerotinia sclerotiorum & Vinodkumar et al., (2017) \\
\hline T. aureoviride, T. harzianum & Cassava & Fusarium solani, Scytalidium lignicola & Da Silva et al., (2016); Silva et al., (2017) \\
\hline T. asperellum, T. viride, $T$. harzianum, $T$. reesei, $T$. virens & Chilli & $\begin{array}{l}\text { Fusarium oxysporum, Phytophthora capsici, Rhizoctonia } \\
\text { solani }\end{array}$ & Jiang et al., (2016); Vinodkumar et al., (2017) \\
\hline T. virens, T. koningii, T. viride, T. harzianum & Groundnut & Athelia rolfsii (as Sclerotium rolfsii) & Hirpara et al., (2016); Hirpara et al., (2017) \\
\hline T. asperellum, T. harzianum, T. gamsii & Maize & Fusarium graminearum, Fusarium verticillioides & $\begin{array}{l}\text { Li et al., (2016); Saravanakumar et al., (2017); He et al., (2019); } \\
\text { Galletti et al., (2020); Lu et al., (2020) }\end{array}$ \\
\hline T. harzianum & Onion & $\begin{array}{l}\text { Stromatinia cepivora, Sclerotium rolfsii (as Sclerotium } \\
\text { rolfsii) }\end{array}$ & Zúñiga-Mendoza \& Ceja-Torres (2017) \\
\hline T. harzianum & Pea & Fusarium oxysporum f. pisi & Checa et al., (2017) \\
\hline T. atroviride, T. harzianum & Rice & Rhizoctonia solani, Sarocladium oryzae & Bora, (2019); Chaudhary et al., (2020) \\
\hline $\begin{array}{l}\text { T. asperelloides, } T \text {. koningiopsis, } T \text {. atroviride, } T \text {. virens, } T \text {. } \\
\text { harzianum }\end{array}$ & Soybean. & $\begin{array}{l}\text { Fusarium virguliforme, Macrophomina phaseolina, } \\
\text { Sclerotinia sclerotiorum }\end{array}$ & $\begin{array}{l}\text { Khaled \& Taheri, (2016); Zhang et al., (2016); Haddad et al., } \\
\text { (2017); Sumida et al., (2018); Pimentel et al., (2020) }\end{array}$ \\
\hline T. harzianum & Sugarcane & Colletotrichum falcatum & Elamathi et al., (2018) \\
\hline T. asperellum, T. harzianum, T. viride & Tomato & Botrytis cinérea, Fusarium oxysporum f. lycopersici & Moosa eta al., (2017); Kuzmanovska et al., (2018) \\
\hline Trichoderma sp., T. harzianum, T. koningii & Wheat & $\begin{array}{l}\text { Bipolaris sorokiniana, Fusarium sudanense, } F . \text { culmorum, } F \text {. } \\
\text { graminearum and } F \text {. verticillioides, Zymoseptoria tritici, } \\
\text { Cochliobolus sativus, Alternaria alternata }\end{array}$ & $\begin{array}{l}\text { Dendouga et al., (2016); Stocco et al., (2016); El-Gremi et al., } \\
\text { (2017); Bhandari et al., (2017); Larran et al., (2020) }\end{array}$ \\
\hline T. harzianum & Yam & Fusarium oxysporum & Nwankiti \& Gwa, (2018) \\
\hline
\end{tabular}

Source: Authors. 
Research, Society and Development, v. 10, n. 15, e296101522465, 2021

(CC BY 4.0) | ISSN 2525-3409 | DOI: http://dx.doi.org/10.33448/rsd-v10i15.22465

\subsection{Use of biochar as management tool of plant diseases}

Biochar has been considered an important tool to management of soilborne phytopatogens, due to its origin and production process, biochar has physicochemical properties and beneficial attributes (Medeiros et al., 2021). Biochar is a solid compound, rich in $\mathrm{C}$ obtained through the combustion of organic materials and could be produced from several types of raw material, such as agricultural waste, wood, and sewage sludge (Lehmann et al., 2011). The high carbon C in the biochar makes it an excellent source of substrate for microorganisms. Biochar remains in the soil for long periods, improving the physical, chemical, and biological soil attributes (Lima et al., 2018). Moreover, it shows high CEC, raises the pH, and increases water retention in the soil (Foster et al., 2016).

In addition, its high porosity and pore size provide an ideal habitat for the growth of microorganisms, which can ensure greater survival of beneficial microorganisms in the soil (Muter et al., 2017; Jaiswal et al., 2018). For example, the use of biochar changes the soil microbiome and can be as inoculant carrier of bacteria consortium against Fusarium sp., as these bacteria remain viable after more than six months of storage (Elhadidy, 2019) and is capable of plant growth promotion due to promote the nutrient availanility in the soil. Ajeng et al. (2020) showed that biochar act to the retention of nutrients to avoid being mathabolized by other phytophatogenic microrganisms or to leaching. This imputs plays an important role in the selective promotion of functional microorganism to dominate the soil microbial community (Liu et al., 2020), promoted root colonization by native arbuscular mycorrhiza and enriches the microbial network (Ajeng et al. 2020), as T. aureoviride (Medeiros et al., 2020b).

\subsection{Plant disease control mechanisms by biochar}

The (Medeiros et al., 2021) showed in a critical review in which $70 \%$ of the studies validated biochar as a strategy to manage diseases caused by pathogens in the soil. Studies show that biochar applied to the soil acts directly or indirectly in suppressing plant disease through mechanisms, such as (i) induction to plant resistance, (ii) sorption of allelopathic and fungitoxic compounds to the plant, (iii) increase of beneficial microorganisms, (iv) changes in the soil attributes that promote health and nutrient availability, and (v) changes of abiotic conditions that provide different management mechanisms for disease suppression (Figure 1). 
Research, Society and Development, v. 10, n. 15, e296101522465, 2021

(CC BY 4.0) | ISSN 2525-3409 | DOI: http://dx.doi.org/10.33448/rsd-v10i15.22465

Figure 1: Mechanisms of Trichoderma spp. and biochar for the management of plant diseases caused by soilborne pathogens.

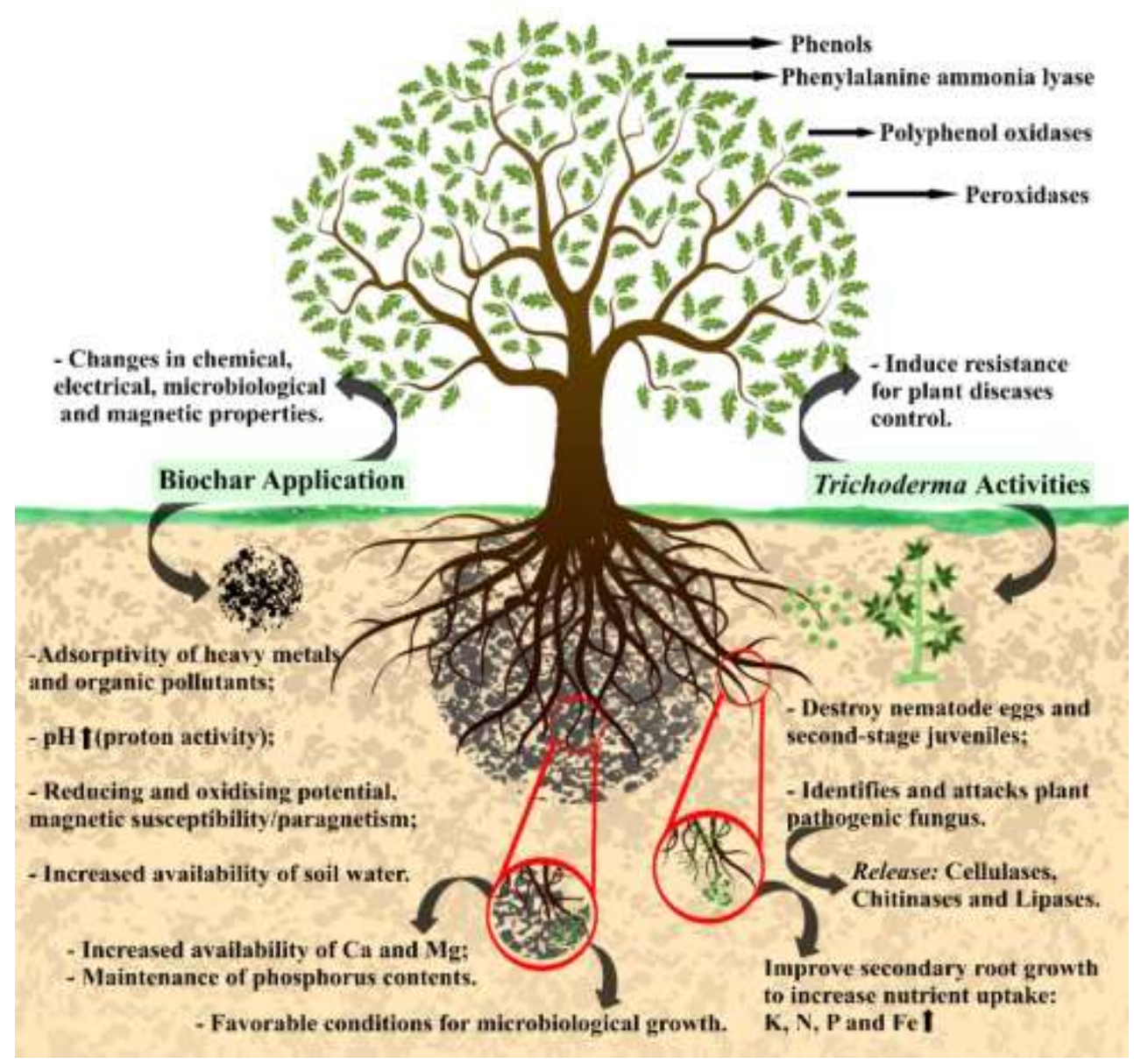

Source: Adapted from Medeiros et al (2021).

\subsection{Combined use of Trichoderma spp. and biochar in the management of plant diseases caused by soilborne pathogen}

A better understanding of the use of biochar from different alternative waste sources with Trichoderma spp. (TRI), and the relationship between plant disease and environmental parameters would increase our ability to set priorities. Few studies reported the effects of the co-application of biochar with Trichoderma. (Medeiros et al., 2020a) and (Medeiros et al., 2020b) demonstrated the positive effects of the combined use of biochar and T. aureoviride on plant growth (melon and watermelon) and on the quality of sandy soils. Muter et al. (2017) observed that biochar applied in combination with Trichoderma increased germination and height of corn plants (Zea mays L.). Sani et al. (2020) showed that the co-application of biochar with Trichoderma promoted synergistically growth and flowering in tomato plants.

The effective growth promotion of antagonistic function of microorganisms against pathogens, as is the case of Trichoderma spp., are promoted due to the capacity of biochar to provide substrate and a shelter to these microorganisms, increasing the effectiveness of biological control (Muter et al., 2017). The porous structure of biochar allows the best development of plant roots, improving absorption of water and nutrients as well as significantly increasing biomass uptake to 
the entire plant. Biochar allows the increase of nutrients and their bioavailability in the soil. Moreover, Trichoderma spp. ensures better absorption and assimilation of these nutrients by the plant, favored by the use of biochar, providing advantages to the soil-plant system (Jaiswal et al., 2018).

The use of biochar and Trichoderma spp. promotes agricultural practices in a more sustainable way by reducing the use of synthetic fertilizers, minimizing the use of chemicals for disease control, while reducing the use of inputs to increase agricultural productivity, mitigating the impacts caused to the environment by food production thus producing healthier foods (Figure 1). Overall, our findings expand our knowledge about the reuse of wastes transformed in biochar, an alternative management tool of plant disease and add important information that can be suitable for development of strategy for use in the global health concept.

\section{Conclusion}

The use of biochar and Trichoderma spp. is a potential and low-cost alternative to sustainable agricultural production. Their interaction promotes a series of benefits to soil quality and plant growth, reducing the use of synthetic products, increasing sustainable production and food security. This review showed that the biochar has potential for the formulation of new products, as it enhances the competitive power of Trichoderma spp. at the soil. Both can act as a powerful alternative tool to control plant diseases caused by pathogens inhabiting the soil, through different mechanisms. Future research should focus on exploring highly efficient strains, optimizing conditions, and assessing a comprehensive number of waste sources for biochar production as well as their efficacy in field experiments.

\section{Acknowledgments}

This work was supported by the CNPq, Conselho Nacional de Desenvolvimento Científico e Tecnológico - Brazil under Grant (process $\mathrm{n}^{\circ}$ 153560/2018-5; 313174/2018-0; 426497/2018-0; 391 307335/2017-8; ONDACBC: 465764/2014-2 and NEXUS: 441305/2017-2), by the CAPES under Grant (88887.736369/2017-00) and by FACEPE under Grant (APQ-02235.01/15; APQ-0419-5.01/15; APQ-0431-5.01/17; APQ-0498-3.07/17).

\section{References}

Ajeng, A. A., Abdullah, R., Ling, T. C., Ismail, S., Lau, B. F., Ong, H. C., \& Chang, J. S. (2020). Bioformulation of biochar as a potential inoculant carrier for sustainable agriculture. Environmental Technology \& Innovation, 101168. https://doi org/10 1016/j eti 2020101168

Al-ani, L. K. T., \& Albaayit, S. F. A. (2018). Antagonistic of some Trichoderma against Fusarium oxysporum sp f cubense tropical race 4 (FocTR4). The Eurasia Proceedings of Science, Engineering \& Mathematics, 2, 35-38.

Alfiky, A. (2019). Effects of ultraviolet irradiation on the in vitro antagonistic potential of Trichoderma spp against soil-borne fungal pathogens. Heliyon 5(7), e02111. https://doi org/e0211110 1016/j heliyon 2019 e02111

Bettiol, W., Pinto, Z. V., da Silva, J. C., Forner, C., de Faria, M. R., Pacifico, M. G., Costa, L. S. A. S. (2019). Produtos comerciais à base de Trichoderma Trichod 1:45.

Bhandari, D. (2017). Bio-control ability of Trichoderma species against spot blotch disease (wheat) causing pathogen Bipolaris sorokiniana under in vitro condition. Journal of Bioscience and Agriculture Research, 14(02): 1194-1201. https://doi org/10 18801/jbar 140217 147

Bora, B., \& Ali, M. S. (2019). Evaluation of Microbial Antagonists against Sarocladium oryzae Causing Sheath Rot Disease of Rice (Oryzae sativa L). International Journal of Current Microbiology and Applied Sciences, 8(7), 1755-1760. https://doi org/10 20546/ijcmas 2019 807 208

Chagas. L. F. B., Junior, A. F. C., Soares, L. P., \& Fidelis, R. R. (2017). Trichoderma na promoção do crescimento vegetal. Journal of Neotropical Agriculture, 4(3): 97-102. https://doi org/10 32404/rean v4i3 1529

Chaudhary, S., Sagar, S., Lal, M., Tomar, A., Kumar, V., \& Kumar, M. (2020). Biocontrol and growth enhancement potential of Trichoderma spp against Rhizoctonia solani causing sheath blight disease in rice. Journal of Environmental Biology, 41(5), 1034-1045. https://doi org/10 22438/jeb/41/5/MRN-1303 
Research, Society and Development, v. 10, n. 15, e296101522465, 2021

(CC BY 4.0) | ISSN 2525-3409 | DOI: http://dx.doi.org/10.33448/rsd-v10i15.22465

Checa, C. O. E., Toro, C. M., \& Descanse, V. J. (2017). Antagonism of Trichoderma spp. strains against pea (Pisum sativum L.) Fusarium wilt caused by Fusarium oxysporum f. sp. pisi. Acta Agronómica, 66(3), 442-448.

Cherkupally, R., Amballa, H., \& Reddy, B. N. (2017). In vitro antagonistic activity of Trichoderma species against Fusarium oxysporum $\mathrm{f}$ sp melongenae. International Journal of Applied Agricultural Research, 12(1), 87-95.

Coelho. L., Reis, M., Guerrero, C., \& Dionísio, L. (2020). Use of organic composts to suppress bentgrass diseases in Agrostis stolonifera. Biological control, 141, 104154. https://doi org/10 1016/j biocontrol 2019104154

Da Silva, J. A. T., de Medeiros, E. V., da Silva, J. M., Tenório, D. D. A., Moreira, K. A., Nascimento, T. C. E. D. S., \& Souza-Motta, C. (2016). Trichoderma aureoviride URM 5158 and Trichoderma hamatum URM 6656 are biocontrol agents that act against cassava root rot through different mechanisms. Journal of Phytopathology, 164(11-12), 1003-1011. https://doi org/10 1111/jph 12521

Dendouga, W., Boureghda, H., \& Belhamra, M. (2016). Biocontrol of wheat Fusarium crown and root rot by Trichoderma spp and evaluation of their cell wall degrading enzymes activities. Acta Phytopathologica et Entomologica Hungarica, 51(1), 1-12. https://doi org/10 1556/038 512016

Elamathi, E., Malathi, P., Viswanathan, R., \& Sundar, A. R. (2018). Expression analysis on mycoparasitism related genes during antagonism of Trichoderma with Colletotrichum falcatum causing red rot in sugarcane. Journal of Plant Biochemistry and Biotechnology, 27(3), 351-361. https://doi org/10 1007/s13562018-0444-z

El-Gremi, S. M., Draz, I. S., \& Youssef, W. A. E. (2017). Biological control of pathogens associated with kernel black point disease of wheat. Crop Protection, 91, 13-19. http://dx doi org/10 1016/j cropro 201608034 0261-2194

Elhadidy, A. E. (2019). Performance of some new bioformulations against tomato fusarium wilt. Egyptian Journal of Desert Research, 69(1), 1-19. http://dx doi org/10 21608/ejdr 2019101621022

Elshahawy, I. E., \& El-Mohamedy, R. S. (2019). Biological control of Pythium damping-off and root-rot diseases of tomato using Trichoderma isolates employed alone or in combination. Journal of Plant Pathology, 101(3), 597-608. https://doi org/10 1007/s42161-019-00248-z

Foster, E. J., Hansen, N., Wallenstein, M., \& Cotrufo, M. F. (2016). Biochar and manure amendments impact soil nutrients and microbial enzymatic activities in a semi-arid irrigated maize cropping system. Agriculture, Ecosystems \& Environment, 233: 404-414. https://doi org/10 1016/j agee 201609 029

Galletti, S., Paris, R., \& Cianchetta, S. (2020) Selected isolates of Trichoderma gamsii induce different pathways of systemic resistance in maize upon Fusarium verticillioides challenge. Microbiological Research, 233, 126406. https://doi org/10 1016/j micres 2019126406

Ghorbanpour, M., Omidvari, M., Abbaszadeh-Dahaji, P., Omidvar, R., \& Kariman, K. (2018). Mechanisms underlying the protective effects of beneficial fungi against plant diseases. Biological Control, 117, 147-157. https://doi org/10 1016/j biocontrol 201711006

Haddad, P. E., Leite, L. G., Lucon, C. M. M., \& Harakava, R. (2017). Selection of Trichoderma spp strains for the control of Sclerotinia sclerotiorum in soybean. Pesquisa Agropecuária Brasileira, 52(12), 1140-1148.

He, A. L., Jia, Liu., Wang, X. H., Zhang, Q. G., Wei, S., \& Jie, C. (2019). Soil application of Trichoderma asperellum GDFS1009 granules promotes growth and resistance to Fusarium graminearum in maize. Journal of Integrative Agriculture, 18(3), 599-606.

Hirpara, D. G., Gajera, H. P., Hirpara, H. Z., \& Golakiya, B. A. (2016). Molecular diversity and fingerprints of Trichoderma associated with antagonistic potentials against Sclerotium rolfsii Sacc. Journal of Plant Diseases and Protection, 124(1), 31-40. https://doi org/10 1007/s41348-016-0053-9

Hirpara, D. G., Gajera, H. P., Hirpara, H. Z., \& Golakiya, B. A. (2017). Antipathy of Trichoderma against Sclerotium rolfsii Sacc: evaluation of cell walldegrading enzymatic activities and molecular diversity analysis of antagonists. Journal of Molecular Microbiology and Biotechnology, 27(1): 22-28. https://doi org/10 1159/000452997

Hong, S., Jv, H., Lu, M., Wang, B., Zhao, Y., \& Ruan, Y. (2020). Significant decline in banana Fusarium wilt disease is associated with soil microbiome reconstruction under chilli pepper-banana rotation. European Journal of Soil Biology, 97, 103154. https://doi org/10 1016/j ejsobi 2020103154

Jaiswal, A. K., Elad, Y., Cytryn, E., Graber, E. R., \& Frenkel, O. (2018). Activating biochar by manipulating the bacterial and fungal microbiome through pre-conditioning. New Phytologist, 219(1), 363-377. https://doi org/10 1111/nph 15042

Jiang, H., Zhang, L., Zhang, J. Z., Ojaghian, M. R., \& Hyde, K. D. (2016). Antagonistic interaction between Trichoderma asperellum and Phytophthora capsici in vitro. Journal of Zheijang University Science B, 17(4), 271-281. http://dx doi org/10 1631/jzus B1500243

Kazerooni, E. A., Al-Shibli, H., Nasehi, A., \& Al-Sadi, A. M. (2020). Endophytic Enterobacter cloacae exhibits antagonistic activity against Pythium damping-off of cucumber. Ciência Rural, 50(8), e20191035. https://doi org/10 1590/0103-8478cr20191035

Khaled, N., \& Taheri, P. (2016). Biocontrol mechanisms of Trichoderma harzianum against soybean charcoal rot caused by Macrophomina phaseolina. Journal of Plant Protection Research, 56(1), 21-31. https://doi org/10 1515/jppr-2016-0004

Khalili, E., Javed, M. A., Huyop, F., Rayatpanah, S., Jamshidi, S., \& Wahab, R. A. (2016). Evaluation of Trichoderma isolates as potential biological control agent against soybean charcoal rot disease caused by Macrophomina phaseolina. Biotechnology \& Biotechnological Equipment, 30(3), 479-488. https://doi org/10 1080/13102818 20161147334

Kumar, G., Maharshi, A., Patel, J., Mukherjee, A., Singh, H. B., \& Sarma, B. K. (2017). Trichoderma: a potential fungal antagonist to control plant diseases. SATSA Mukhapatra Annual Technical Issue, 21, 206-218. 
Research, Society and Development, v. 10, n. 15, e296101522465, 2021 (CC BY 4.0) | ISSN 2525-3409 | DOI: http://dx.doi.org/10.33448/rsd-v10i15.22465

Kuzmanovska, B., Rusevski, R., Jankulovska, M., \& Oreshkovikj, K. B. (2018). Antagonistic activity of Trichoderma asperellum and Trichoderma harzianum against genetically diverse Botrytis cinerea isolates. Chilean Journal of Agricultural Research, 78(3), 391-399. http://dx doi org/10 4067/S071858392018000300391

Larkin, R. P., \& Brewer, M. T. (2020). Effects of crop rotation and biocontrol amendments on Rhizoctonia disease of potato and soil microbial communities. Agriculture 10(4), 128. https://doi org/10 3390/agriculture10040128

Larran, S., Santamarina, S. M. P., Roselló, C. J., Simón, M. R., \& Perelló, A. (2020). In vitro antagonistic activity of Trichoderma harzianum against Fusarium sudanense causing seedling blight and seed rot on wheat. ACS omega, 5(36), 23276-23283. https://doi org/10 1021/acsomega 0c03090

Lee, S., Yap, M., Behringer, G., Hung, R., \& Bennett, J. W. (2016). Volatile organic compounds emitted by Trichoderma species mediate plant growth. Fungal Biology and Biotechnology, 3(1), 1-14. https://doi org/10 1186/s40694-016-0025-7

Lehmann, J., Rillig, M. C., Thies, J., Masiello, C. A., Hockaday, W. C., \& Crowley, D. (2011). Biochar effects on soil biota-a review. Soil Biology \& Biochemistry, 43(9), 1812-1836. https://doi org/10 1016/j soilbio 201104022

Li, Y., Sun, R., Yu, J., Saravanakumar, K., \& Chen, J. (2016). Antagonistic and biocontrol potential of Trichoderma asperellum ZJSX5003 against the maize stalk rot pathogen Fusarium graminearum. Indian Journal of Microbiology Research, 56(3), 318-327. https://doi org/10 1007/s12088-016-0581-9

Lima, J. R., de Moraes, S. W., de Medeiros, E. V., Duda, G. P., Corrêa, M. M., Martins Filho, A. P., \& Hammecker, C. (2018). Effect of biochar on physicochemical properties of a sandy soil and maize growth in a greenhouse experiment. Geoderma, 319, 14-23. https://doi org/10 1016/j geoderma 2017 12033

Liu, J., Ding, Y., Ji, Y., Gao, G., \& Wang, Y. (2020). Effect of maize straw biochar on bacterial communities in agricultural soil. Bulletin of Environmental Contamination and Toxicology, 104: 333-338. http://dx doi org/10 1007/s00128-020-02793-1

Lu, Z. X., Tu, G. P., Zhang, T., Li, Y. Q., Wang, X., H., Zhang, Q. G., \& Jie, C. (2020). Screening of antagonistic Trichoderma strains and their application for controlling stalk rot in maize. Journal of Integrative Agriculture, 19(1), 145-152. https://doi org/10 1016/S2095-3119(19)62734-6

Moosa, A., Sahi, S. T., Haq, I. U., Farzand, A., Khan, S. A., \& Javaid, K. (2017). Antagonistic potential of Trichoderma isolates and manures against Fusarium wilt of tomato. International Journal of Vegetable Science, 23(3), 207-218. https://doi org/10 1080/19315260 20161232329

Muter, O., Grantina-Ievina, L., Makarenkova, G., Vecstaudza, D., Strikauska, S., Selga, T., \& Steiner, C. (2017). Effect of biochar and Trichoderma application on fungal diversity and growth of Zea mays in a sandy loam soil. Environmental and Experimental Biology, 15(4), 289-296. https://doi org/10 22364/eeb 1530

Medeiros, E. V., Moraes, M. C., Costa, D. P., Silva, J. S., Oliveira, J. B., José, R. S., \& Hammecker, C. (2020a). Biochar and Trichoderma aureoviride applied to the sandy soil: effect on soil quality and watermelon growth. Notulae Botanicae Horti Agrobotanici Cluj-Napoca, 48(2), 735-751. https://doi org/10 $15835 /$ nbha48211851

Medeiros, E. V., Moraes, M. C. H. S., Costa, D. P., Duda, G. P., Oliveira, J. B., Silva, J. A., Lima, J. R. S., \& Hammecker, C. (2020b). Effect of biochar and inoculation with Trichoderma aureoviride on melon growth and sandy Entisol quality. Australian Journal of Crop Science. 14(06), 971-977. https://doi org/10 21475/ajcs 201406 p2302

Medeiros, E. V., Lima, N. T., de Sousa Lima, J. R., Pinto, K. M., S., da Costa, D. P., Junior, C. L. F., \& Hammecker, C. (2021). Biochar as a strategy to manage plant diseases caused by pathogens inhabiting the soil: a critical review. Phytoparasitica 1, 1-14. https://doi org/10 1007/s12600-021-00887-y

Montiel-Rozas, D. M., M., Hurtado-Navarro, M., Díez-Rojo, M. Á., Pascual, J. A., \& Ros, M. (2019). Sustainable alternatives to 1, 3-dichloropropene for controlling root-knot nematodes and fungal pathogens in melon crops in Mediterranean soils: Efficacy and effects on soil quality. Environmental Pollution, $247,1046-1054$.

Nawaz, K., Shahid, A. A., Bengyella, L., Subhani, M. N., Ali, M., Anwar, W., \& Ali, S. W. (2018). Diversity of Trichoderma species in chili rhizosphere that promote vigor and antagonism against virulent Phytophthora capsici. Scientia Horticulturae, 239, 242-252. https://doi org/10 1016/j scienta 2018 05 048

Nawrocka, J., \& Małolepsza, U. (2013). Diversity in plant systemic resistance induced by Trichoderma. Biological control, 67(2), 149-156. https://doi org/10 1016/j biocontrol 201307005

Nwankiti, A. O., \& Gwa, V. I. (2018). Evaluation of antagonistic effect of Trichoderma harzianum against Fusarium oxysporum causal agent of white yam (Dioscorearotundata poir) tuber rot. Trends in Technical \& Scientific Research, 1(1), 555554. https://doi org/10 19080/TTSR 2018 01 555554

Pimentel, M. F., Arnão, E., Warner, A. J., Subedi, A., Rocha, L. F., Srour, A., \& Fakhoury, A. M. (2020). Trichoderma isolates inhibit Fusarium virguliforme growth, reduce root rot, and induce defense-related genes on soybean seedlings. Plant Disease, 104(7), 1949-1959. https://doi org/10 1094/PDIS-08-191676-RE

Sallam, N. M., Eraky, A. M., \& Sallam, A. (2019). Effect of Trichoderma spp on Fusarium wilt disease of tomato. Molecular Biology Reports, 46(4), 44634470. https://doi org/10 1007/s11033-019-04901-9

Sani, M. N. H., Hasan, M., Uddain, J., \& Subramaniam, S. (2020). Impact of application of Trichoderma and biochar on growth, productivity and nutritional quality of tomato under reduced NPK fertilization. Annals of Agricultural Sciences, 65(1), 107-115. https://doi org/10 1016/j aoas 2020 06 003

Saravanakumar, K., Li, Y., Yu, C., Wang, Q. Q., Wang, M., Sun, J., \& Chen, J. (2017). Effect of Trichoderma harzianum on maize rhizosphere microbiome and biocontrol of Fusarium Stalk rot. Scientific Reports, 7(1), 1-13. https://doi org/10 1038/s41598-017-01680-w 
Research, Society and Development, v. 10, n. 15, e296101522465, 2021 (CC BY 4.0) | ISSN 2525-3409 | DOI: http://dx.doi.org/10.33448/rsd-v10i15.22465

Silva, J. A. T., de Medeiros, E. V., da Silva, J. M., Tenório, D. D. A., Moreira, K. A., da Silva Nascimento, T. C. E., \& Souza-Motta, C. (2017). Antagonistic activity of Trichoderma spp against Scytalidium lignicola CMM 1098 and antioxidant enzymatic activity in cassava. Phytoparasitica, 45(2), 219-225. https://doi org/10 1007/s12600-017-0578-x

Silva, C. C. G. D., Medeiros, E. V. D., Fracetto, G. G. M., Fracetto, F. J. C., Martins Filho, A. P., Lima, J. R. D. S., \& Hammecker, C. (2021). Coffee waste as an eco-friendly and low-cost alternative for biochar production impacts on sandy soil chemical attributes and microbial gene abundance. Bragantia. 80 . https://doi org/10 1590/1678-4499 20200459

Stocco, M. C., Mónaco, C. I., Abramoff, C., Lampugnani, G., Salerno, G., Kripelz, N., \& Consolo, V. F. (2016). Selection and characterization of Argentine isolates of Trichoderma harzianum for effective biocontrol of Septoria leaf blotch of wheat. World Journal of Microbiology \& Biotechnology, 32(3), 49. https://doi org/10 1007/s11274-015-1989-9

Sumida, C. H., Daniel, J. F., Araujod, A. P. C., Peitl, D. C., Abreu, L. M., Dekker, R. F., \& Canteri, M. G. (2018). Trichoderma asperelloides antagonism to nine Sclerotinia sclerotiorum strains and biological control of white mold disease in soybean plants. Biocontrol Science and Technology, 28(2), 142-156. https://doi org/10 1080/09583157 20181430743

Vinodkumar, S., Indumathi, T., \& Nakkeeran, S. (2017). Trichoderma asperellum (NVTA2) as a potential antagonist for the management of stem rot in carnation under protected cultivation. Biological control, 113, 58-64. https://doi org/10 1016/j biocontrol 201707001

Wang, K. D., Borrego, E. J., Kenerley, C. M., \& Kolomiets, M. V. (2020) Oxylipins other than jasmonic acid are xylem-resident signals regulating systemic resistance induced by Trichoderma virens in maize. The Plant Cell, 32(1), 166-185. https://doi org/10 1105/tpc 19 00487

Zhang, F., Ge, H., Zhang, F., Guo, N., Wang, Y., Chen, L., \& Li, C. (2016). Biocontrol potential of Trichoderma harzianum isolate T-aloe against Sclerotinia sclerotiorum in soybean. Plant Physiology and Biochemistry, 100, 64-74. http://dx doi org/10 1016/j plaphy 201512017

Zin, N. A., \& Badaluddin, N. A. (2020). Biological functions of Trichoderma spp for agriculture applications. Annals of Agricultural Sciences, 65(2), 168178. http://dx doi org/10 1016/j aoas

Zúñiga-Mendoza, E., \& Ceja-Torres, L. F. (2017). In vitro antagonism of Trichoderma harzianum on Sclerotium cepivorum Berk and S rolfsii Sacc, causal agents of onion rot Phyton. Inter. Journal of Experimental Botany, 86, 7-13. http://dx doi org/10 32604/phyton 2017 86 007 